\title{
Soil Compaction Vulnerability at Organ Pipe Cactus National Monument, Southwestern Arizona
}

Open-File Report 2014-1048 



\section{Soil Compaction Vulnerability at Organ Pipe Cactus National Monument, Southwestern Arizona}

By Robert H. Webb, Kenneth E. Nussear, Shinji Carmichael, and Todd C. Esque

Open-File Report 2014-1048

U.S. Department of the Interior

U.S. Geological Survey 


\section{U.S. Department of the Interior \\ SALLY JEWELL, Secretary}

\section{U.S. Geological Survey \\ Suzette M. Kimball, Acting Director}

U.S. Geological Survey, Reston, Virginia: 2014

For more information on the USGS-the Federal source for science about the Earth,

its natural and living resources, natural hazards, and the environment-visit

http://www.usgs.gov or call 1-888-ASK-USGS

For an overview of USGS information products, including maps, imagery, and publications, visit $h$ ttp://www.usgs.gov/pubprod

To order this and other USGS information products, visit http://store.usgs.gov

Suggested citation:

Webb, R.H, Nussear, K.E., Carmichael, Shinji, and Esque, T.C., 2014, Soil compaction vulnerability at Organ Pipe Cactus National Monument, Arizona: U.S. Geological Survey Open-File Report 2014-1048, 24 p., http://dx.doi.org/10.3133/ofr20141048.

ISSN 2331-1258 (online)

Any use of trade, product, or firm names is for descriptive purposes only and does not imply endorsement by the U.S. Government.

Although this report is in the public domain, permission must be secured from the individual copyright owners to reproduce any copyrighted material contained within this report. 


\section{Contents}

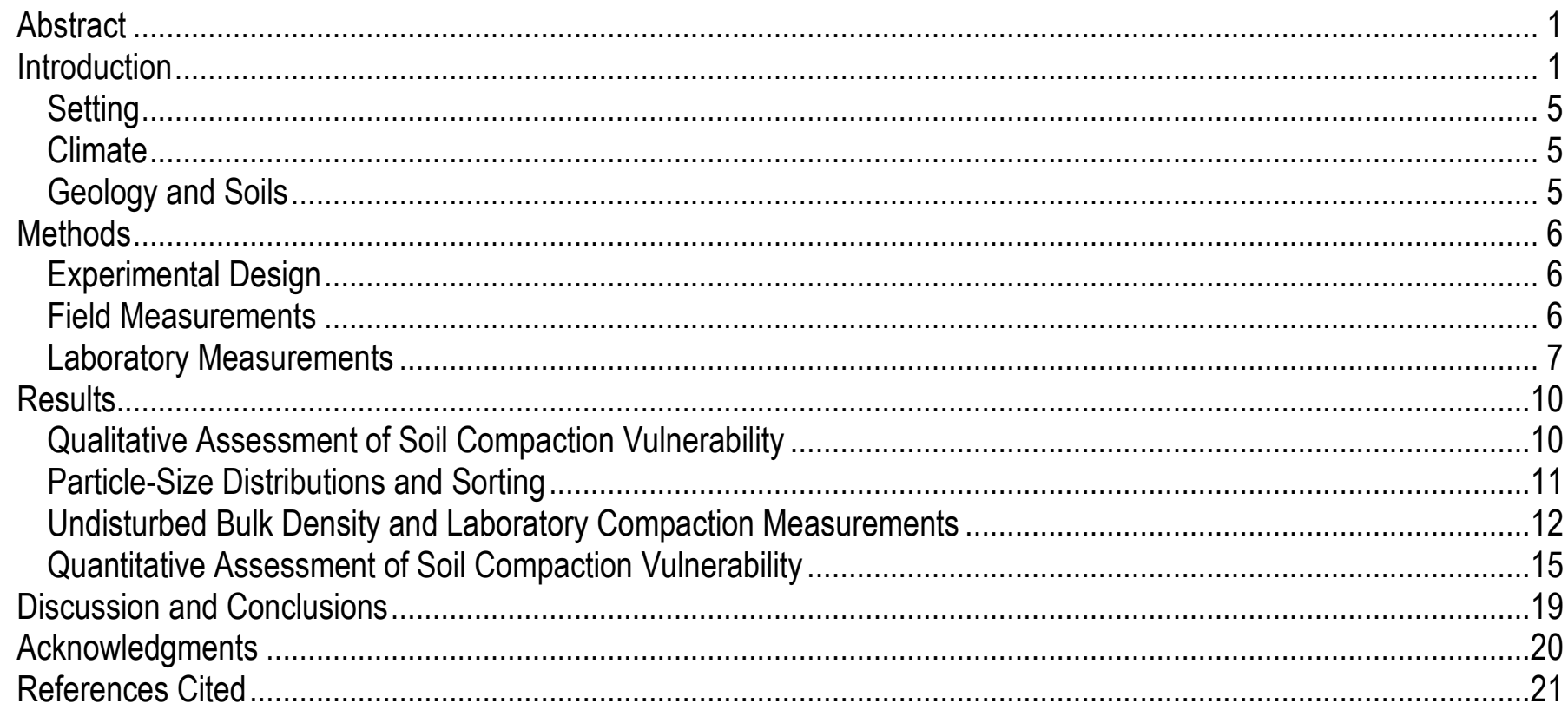

\section{Figures}

Figure 1. Map showing spatial distribution of soils by vulnerability classifications and the locations of

soil sampling points, Organ Pipe Cactus National Monument, southwestern Arizona

Figure 2. Three examples of Proctor compaction curves illustrating low, medium, and high vulnerability to soil compaction at Organ Pipe Cactus National Monument, southwestern Arizona.

Figure 3. Proctor curves illustrating some of the characteristics used to calculate soil vulnerability to compaction .... 8

Figure 4. Ternary diagram showing particle-size distributions for 48 soil samples analyzed for compaction vulnerability at Organ Pipe Cactus National Monument, southwestern Arizona

Figure 5. Histogram showing Folk sorting coefficients for soil samples from Organ Pipe Cactus National Monument, southwestern Arizona

Figure 6. Histograms showing Proctor compaction curves (see fig. 3) for (A) maximum bulk density minus undisturbed bulk density ( $\left.D_{\max }-D_{u d}\right),(B)$ maximum minus minimum bulk density $\left(D_{\max }-D_{\min }\right),(C)$ water content at maximum density, and $(D)$ water content at minimum density, with the scoring system for compaction vulnerability shown in groups delineated with dashed lines.

Figure 7. Graphs showing maximum soil strength compared to (A) moisture content, (B) bulk density, and (C) Folk sorting coefficient, $\sigma_{i}$.

Figure 8. Map showing soil vulnerability to soil compaction based on laboratory measurements, Organ Pipe Cactus National Monument, southwestern Arizona ...

Figure 9. Map showing changes in classifications of soil compaction vulnerability from qualitative (fig. 1) to quantitative (fig. 8) assessments, Organ Pipe Cactus National Monument, southwestern Arizona. 


\section{Tables}

Table 1. Soil vulnerability classifications of Organ Pipe Cactus National Monument

Table 2. Vulnerability scores for selected laboratory measurements of compaction of soils at Organ Pipe Cactus National Monument, southwestern Arizona

Table 3. Undisturbed dry bulk densities for soils at Organ Pipe Cactus National Monument, southwestern Arizona

\section{Conversion Factors and Datums}

\section{Conversion Factors}

SI to Inch/Pound

\begin{tabular}{lll}
\hline \multicolumn{1}{c}{ Multiply } & By & \multicolumn{1}{c}{ To obtain } \\
\hline & Length & \\
\hline centimeter $(\mathrm{cm})$ & 0.3937 & inch (in.) \\
millimeter $(\mathrm{mm})$ & 0.03937 & inch (in.) \\
meter $(\mathrm{m})$ & 3.281 & foot (ft) \\
kilometer $(\mathrm{km})$ & 0.6214 & mile (mi) \\
\hline & Area & \\
\hline hectare $($ ha) & 2.471 & acre \\
\hline & Volume & \\
\hline cubic centimeter $\left(\mathrm{cm}^{3}\right)$ & 0.06102 & cubic inch $\left(\mathrm{in}^{3}\right)$ \\
\hline & Density & \\
\hline kilogram per cubic meter $\left(\mathrm{kg} / \mathrm{m}^{3}\right)$ & 0.06242 & pound per cubic foot $\left(\mathrm{lb} / \mathrm{ft}^{3}\right)$ \\
\hline
\end{tabular}

Temperature in degrees Celsius $\left({ }^{\circ} \mathrm{C}\right)$ may be converted to degrees Fahrenheit $\left({ }^{\circ} \mathrm{F}\right)$ as follows: ${ }^{\circ} \mathrm{F}=\left(1.8 \mathrm{x}^{\circ} \mathrm{C}\right)+32$.

\section{Datums}

Vertical coordinate information is referenced to the North American Vertical Datum of 1988 (NAVD 88).

Horizontal information in geographic coordinates is referenced to the World Geodetic System 1984 (WGS 84).

Elevation, as used in this report, refers to distance above the vertical datum. 


\title{
Soil Compaction Vulnerability at Organ Pipe Cactus National Monument, Southwestern Arizona
}

\author{
By Robert H. Webb, Kenneth E. Nussear, Shinji Carmichael, and Todd C. Esque
}

\section{Abstract}

Compaction vulnerability of different types of soils by hikers and vehicles is poorly known, particularly for soils of arid and semiarid regions. Engineering analyses have long shown that poorly sorted soils (for example, sandy loams) compact to high densities, whereas well-sorted soils (for example, eolian sand) do not compact, and high gravel content may reduce compaction. Organ Pipe Cactus National Monument (ORPI) in southwestern Arizona, is affected greatly by illicit activities associated with the United States-Mexico border, and has many soils that resource managers consider to be highly vulnerable to compaction. Using geospatial soils data for ORPI, compaction vulnerability was estimated qualitatively based on the amount of gravel and the degree of sorting of sand and finer particles. To test this qualitative assessment, soil samples were collected from 48 sites across all soil map units, and undisturbed bulk densities were measured. A scoring system was used to create a vulnerability index for soils on the basis of particle-size sorting, soil properties derived from Proctor compaction analyses, and the field undisturbed bulk densities. The results of the laboratory analyses indicated that the qualitative assessments of soil compaction vulnerability underestimated the area of high vulnerability soils by 73 percent. The results showed that compaction vulnerability of desert soils, such as those at ORPI, can be quantified using laboratory tests and evaluated using geographic information system analyses, providing a management tool that managers potentially could use to inform decisions about activities that reduce this type of soil disruption in protected areas.

\section{Introduction}

Land uses in the North American deserts that cause soil disruption are widespread and increasing on public lands (Lovich and Bainbridge, 1999; Leu and others, 2008), particularly on vehicle roads and tracks (Vogel and Hughson, 2009) and unauthorized trails attributed to immigration, drug smuggling, and interdiction by federal authorities near the United States-Mexico borderlands (U.S. Fish and Wildlife Service, 2011). An understanding of the spatial variability of soil vulnerability to compaction could contribute to land management that minimizes the adverse effects of these uses (Jones and others, 2003). Compaction and its effects on soil properties are recognized widely in agricultural (Vorhees and others, 1978) and engineering practices (Fredlund and Rahardjo, 1993), as well as off-road vehicle use (Webb, 1983; Webb and others, 2013), livestock grazing (Brooks and others, 2006; Chen and others, 2012), human trampling (Liddle, 1975; Liddle and Grieg-Smith, 1975; Weaver and Dale, 1978), and construction of utility corridors (Vasek and others, 1975). Military exercises involving extensive vehicle use, in particular, cause substantial soil compaction and surface disruption (Krzysik, 1985; McCarthy, 1996; Prose and Wilshire, 2000). 
Soil compaction has negative environmental effects that may persist for decades to centuries (Webb, 2002). Compaction decreases infiltration rates and increases runoff, thus accelerating soil erosion (Snyder and others, 1976; Iverson, 1980; Iverson and others, 1981) and increasing dust production and wind erosion (Campbell, 1972; Goossens and Buck, 2009, 2011), all of which may retard plant establishment (Adams and others, 1982; Prose and others, 1987). Minimizing soil compaction, therefore, is a priority for management of natural areas, particularly national parks (National Park Service, 2006), and the ability to predict the vulnerability of different soils to soil compaction is important in the development of management plans where soil properties may be threatened by adverse land uses.

Vulnerability of soils to compaction is known from studies of engineered fill, where the objective is to maximally compact fill to support roadways or building foundations (Fredlund and Rahardjo, 1993). The magnitude of the increase in density has been shown to depend on the soil moisture content, texture, and the compacting load (Williams and McLean, 1950; Bodman and Constantin, 1965; Webb, 1983). Vehicles moving across soil surfaces cause deformation as normal and shear stresses are applied beneath tires (Muro and O'Brien, 2004). Compaction results when normal and shear stresses applied to a soil surface are greater than soil strength, and this results in deformation of soil structure, particularly decreased pore volume and increased bulk density. If normal stress from surface disturbances is repeated sufficiently, soils compact to a maximum density for that applied stress. Poorly sorted soils, such as loamy sands and sandy loams, compact more readily than well-sorted soils, such as eolian sand or playa surfaces (Webb, 1983). Increasing amounts of gravel may decrease compaction, even though additional gravel makes the soil more poorly sorted (Webb, 1983); when gravel content is greater than about 30 percent, the larger particles interact, absorbing applied stress.

Soils compact the most when stresses are applied at water contents slightly less than field capacity (water content that a saturated soil drains to after about 24 hours; Webb, 2002). At water contents approaching zero, pore-water pressures are high, increasing the resistance to applied pressure (Greacen, 1960; Webb, 1983), whereas at water contents near saturation, volume decreases can be attained only by forcing water from the soil, and drainage rates become the limiting factor. Low vulnerability soils do not show a large variation over the range in moisture contents, have minima at a moisture content of 0 , and (or) have maximum density at a relatively high moisture content that may create drainage problems. Soils that are waterlogged generally deform rather than compact.

The purpose of this paper is to quantify compaction vulnerability for desert soils at Organ Pipe Cactus National Monument (ORPI), southwestern Arizona (fig. 1). Immigration, smuggling, border security interdiction, and visitor usage have caused a mosaic of soil compaction and disruption in an area managed for conservation and wilderness (T.C. Esque and others, U.S. Geological Survey, unpub. data, 2010; Webb and others, 2013), and we demonstrate how assessment of compaction vulnerability might be useful for resource assessments and management of disturbances at ORPI, as well as for other arid and semiarid landscapes. Geospatial National Resources Conservation Service (NRCS) Soil Survey Geographic (SSURGO) data were used (termed the National Cooperative Soil Survey [NCSS] data [NRCS, n.d.]) to qualitatively rank soil vulnerability on the basis of particle-size sorting (poor sorting=many different sizes of particles in the soil) and gravel content (more large particles=less vulnerable) (table 1). Soil samples then were analyzed for compaction properties and scoring system was developed for assessing soil vulnerability to compaction from laboratory data. The qualitative and quantitative assessments were compared to show why quantitative analyses are important to the evaluation of compaction vulnerability. 


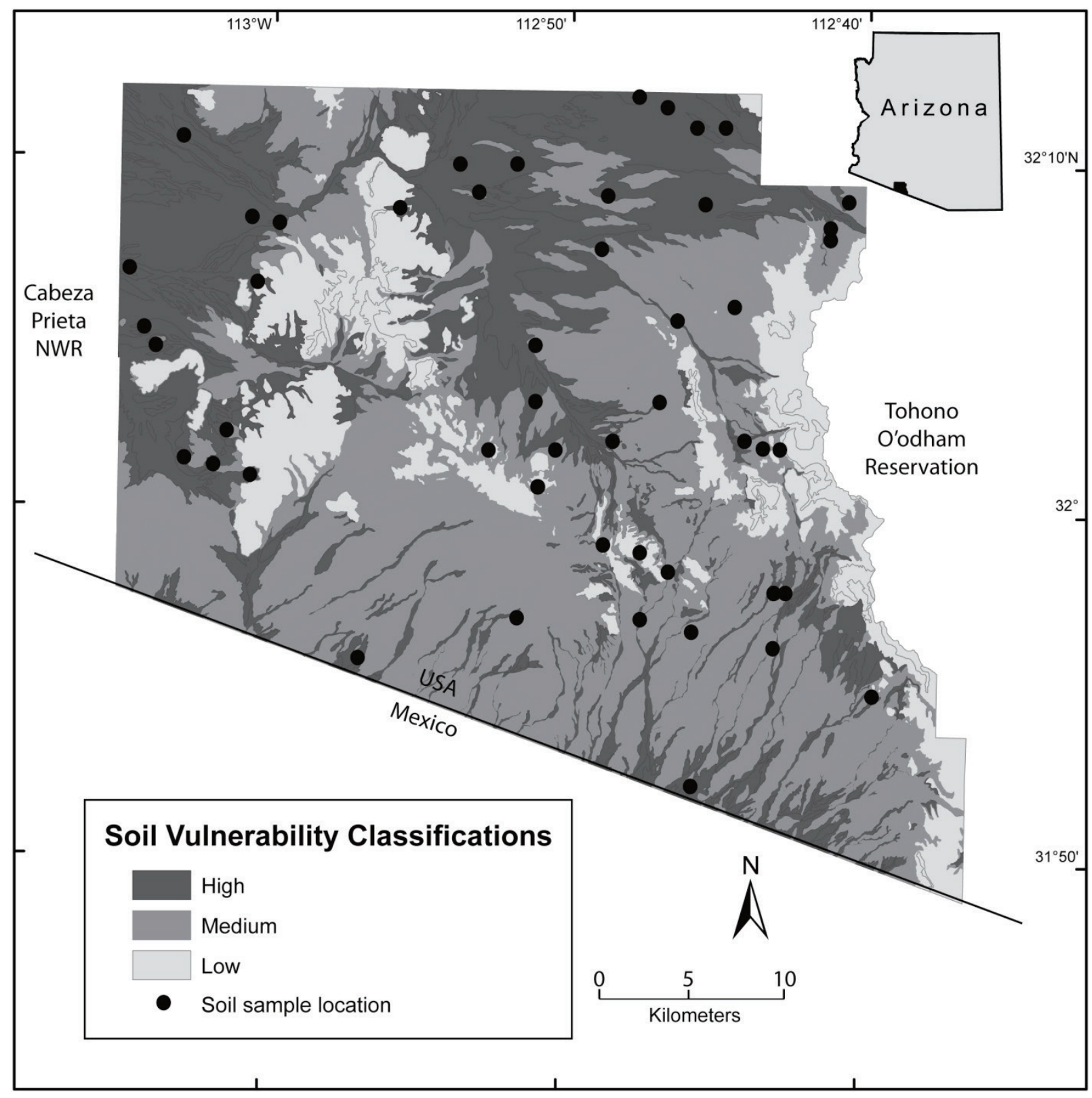

Figure 1. Map showing spatial distribution of soils by vulnerability classifications and the locations of soil sampling points, Organ Pipe Cactus National Monument, southwestern Arizona. Distribution of soils is from Soil Survey Geographic data and qualitative vulnerability classifications (table 1). NWR, National Wildlife Refuge. 
Table 1. Soil vulnerability classifications of Organ Pipe Cactus National Monument, southwestern Arizona.

[Soil map unit: SSURGO data for ORPI: $h t t p: / / s o i l d a t a m a r t . n r c s . u s d a . g o v / M e t a d a t a . a s p x ?$ Survey $=A Z 646 \& U$ seState $=A Z$, accessed July 15, 2012. Abbreviations: ORPI, Organ Pipe Cactus National Monument; SSURGO, Soil Survey Geographic; nd, not determined]

\begin{tabular}{lccccc}
\hline \multicolumn{1}{c}{ Soil map unit } & Hectares & $\begin{array}{c}\text { Extent } \\
\text { (percent) }\end{array}$ & $\begin{array}{c}\text { Qualitative } \\
\text { vulnerability } \\
\text { classification }\end{array}$ & Samples & $\begin{array}{c}\text { Laboratory } \\
\text { vulnerability } \\
\text { classification }\end{array}$ \\
\hline Ajo very cobbly sandy loam & 1,300 & 1.0 & High & 3 & High \\
Ajo very gravelly loam & 4,040 & 3.0 & Medium & 4 & High \\
Antho fine sandy loam & 5,849 & 4.4 & High & 3 & High \\
Antho soils, very gravelly variant & 618 & 0.5 & High & 3 & High \\
Cherioni gravelly very fine sandy loam & 5,044 & 3.8 & High & 4 & High \\
Cipriano gravelly loam & 3,911 & 2.9 & Medium & 3 & Medium \\
Gachado very cobbly loam & 621 & 0.5 & Medium & 1 & High \\
Gilman very fine sandy loam & 10,917 & 8.2 & High & 3 & Medium \\
Gilman very fine sandy loam, saline & 561 & 0.4 & High & 2 & High \\
Growler-Antho Complex & 6,761 & 5.1 & High & 3 & High \\
Gunsight very gravelly loam & 4,091 & 3.1 & Medium & 0 & nd \\
Gunsight very gravelly loam & 24,824 & 18.6 & Medium & 3 & High \\
Harqua very gravelly loam & 213 & 0.2 & Medium & 0 & nd \\
Harqua very cobbly loam & 260 & 0.2 & High & 1 & Medium \\
Harqua-Gunsight Complex & 13,652 & 10.2 & Medium & 2 & High \\
Laveen loam & 723 & 0.5 & High & 3 & Medium \\
Lomitas very stony loam & 13,303 & 9.9 & Medium & 0 & nd \\
Perryville very cobbly fine sandy loam & 774 & 0.6 & High & 2 & Medium \\
Rillito gravelly sandy loam & 8,070 & 6.0 & High & 4 & Medium \\
Rock land & 11,739 & 8.8 & Low & 1 & High \\
Rock outcrop & 1,556 & 1.2 & Low & 0 & nd \\
Stony land- Rock outcrop association & 9,124 & 6.8 & Low & 0 & nd \\
Torrifluvents & 5,862 & 4.4 & High & 3 & High \\
\hline Totals & 133,813 & 100.0 & & 48 & \\
\hline & & & & & \\
\hline
\end{tabular}




\section{Setting}

Organ Pipe Cactus National Monument (ORPI), a unit of the National Park Service (NPS), was established in 1933. ORPI contains 133,800 ha of Sonoran Desert landscape on the United States-Mexico border in southwestern Arizona, sharing a 47.9-km boundary with Mexico (fig. 1). ORPI also shares boundaries with Cabeza Prieta National Wildlife Refuge on the west, the Tohono O'odham Reservation on the east, and a combination of Bureau of Land Management and private lands on the north. Elevations of ORPI range from $297 \mathrm{~m}$ at the United States-Mexico border in the southwestern part of ORPI, to 1,465 $\mathrm{m}$ at the top of Mount Ajo in the Ajo Mountains (fig. 1).

\section{Climate}

The National Park Service (2008) provides details on climate stations and the climate of ORPI. Based on records from the NPS headquarters from 1948 to 2011 (at an elevation of $501 \mathrm{~m}$ ), the mean annual precipitation was $236 \mathrm{~mm}$, July air temperatures averaged $31.5^{\circ} \mathrm{C}$, January air temperatures averaged $12.1^{\circ} \mathrm{C}, 14.1$ freezing days occurred per year, and 84 days per year exceeded a maximum air temperature of $37.7^{\circ} \mathrm{C}$. Monthly precipitation was highest in August $(49.5 \mathrm{~mm})$ and about one-half of the precipitation occurred from June through September as monsoonal thunderstorms. For the Bull Pasture climate station at an elevation of $947 \mathrm{~m}$ in the Ajo Mountains, mean annual precipitation was $290 \mathrm{~mm}$, July air temperatures averaged $29.1^{\circ} \mathrm{C}$, and December air temperatures averaged $11.8{ }^{\circ} \mathrm{C}$. In contrast, for the Growler Wash climate station at an elevation of $370 \mathrm{~m}$, mean annual precipitation was $209 \mathrm{~mm}$, July high air temperature was $39.4{ }^{\circ} \mathrm{C}$, and December air temperatures averaged a low of $4.76^{\circ} \mathrm{C}$.

\section{Geology and Soils}

The geology of ORPI is dominated by Tertiary volcanic and older granitic mountain ranges and Cenozoic alluvial plains (National Park Service, 2010). Using remote sensing, Nauman (2009) showed that the alluvial plains of ORPI could be distinguished based on their source lithologies. Geospatial geologic data (National Park Service, 2010) indicates that 74 percent of the land area of ORPI is alluvial deposits. Surficial geology has been mapped for 41 percent of the area of ORPI (Pearthree and others, 2011; Youberg and Pearthree, 2011; Young and Pearthree, 2011). About 40 percent of the mapped surficial deposits are alluvial deposits of Middle to Late Pleistocene age with moderate to strong soil development, and another 30 percent are surfaces and active channels of Latest Pleistocene to Holocene age with weak soil development. Most of the surficial deposits of the alluvial plains at ORPI do not have desert pavement, but many surfaces, particularly regolith overlying bedrock, have lag gravel armoring the surface.

The soils have been described and mapped for the 133,813-ha area of ORPI (Chamberlain, 1972). Nauman (2009) used remotely sensed data to verify the Chamberlain (1972) map units and added information on lithologic source materials and active fluvial systems, neither of which are important to these analyses. The Natural Resources Conservation Service (NRCS) Soil Survey Geographic (SSURGO) database, the digital equivalent of the Chamberlain (1972) soils maps, provides polygon coverages for all soil-map units and provides a variety of data on each soil map unit, particularly surficial soil particle-size distributions (Natural Resources Conservation Service [n.d.]). The areas given in Chamberlain (1972) differ from the more recent SSURGO data by about 1-2 percent. The SSURGO soil units and areas for ORPI are shown in table 1 . A total of 22,419 ha (17 percent) of ORPI are mapped as bedrock or weathered regolith, and the remaining 83 percent of the land area is composed of relatively deep soils on alluvial fans and plains. 


\section{Methods}

\section{Experimental Design}

The SSURGO surficial soil particle-size distributions were used to qualitatively rank the soils of ORPI by vulnerability classifications of high, medium, and low. Integer scores of 3, 2, and 1 were used strictly for convenience to denote the vulnerability classifications of high, medium, and low, respectively. High vulnerability soils (score $=3$ ) are poorly sorted with gravel content of less than 30 percent, and generally are categorized as sandy loams or loamy sands (table 1 ). Medium vulnerability soils (score $=2$ ) are better sorted in the less-than-2-mm fraction (for example, loams) but also have high gravel content ( $>30$ percent), which presumably would decrease the amount of compaction from surface stresses. Bedrock outcrops, weathered regolith, and very rocky soils were considered to have a low vulnerability for soil compaction (score $=1$ ).

Soil samples for laboratory analysis were collected as part of a larger study on human impacts at ORPI (T.C. Esque and others, U.S. Geological Survey, unpub. data, 2010). The samples were collected using a random stratified experimental design of 211 points distributed evenly between undisturbed and disturbed desert upland sites that were at least $50 \mathrm{~m}$ from xeroriparian channels greater than or equal to 25 $\mathrm{cm}$ deep and (or) $2 \mathrm{~m}$ wide. Random sample points near polygon boundaries were rejected. The study plots were distributed among soil polygons of the three qualitative vulnerability classifications. Field teams located study plots using hand-held GPS units, typically with an accuracy of $\pm 3 \mathrm{~m}$. A total of 48 bulk soil samples were collected from a $75 \times 75 \mathrm{~cm}$ by $10 \mathrm{~cm}$ deep excavation at the center of each plot. These samples typically weighed about $20 \mathrm{~kg}$ and were composed of all material less than $16 \mathrm{~mm}$ in size, as determined with a sieve; most were bulk soil samples containing all particles in the upper $10 \mathrm{~cm}$ of the sampled point.

Because of access restrictions due to safety concerns and difficult topography, we were unable to sample soils by these relative percentages. Instead, 34 soil samples were collected from high vulnerability soils ( 71 percent of samples), 13 samples were collected from medium vulnerability soils ( 27 percent of samples), and only 1 sample was collected from a low vulnerability soil (fig. 1). Therefore, our analyses better illustrate the properties of highly vulnerable soils in laboratory analyses instead of a true test of the range in field compaction vulnerability.

\section{Field Measurements}

A Troxler ${ }^{\circledR} 3440$ Moisture Density Gauge was used to measure undisturbed bulk density and moisture content of soils at ORPI using the American Society for Testing and Materials Standard (ASTM D6938-10). The Troxler ${ }^{\circledR} 3440$ uses a dual source of cesium-137 $\left({ }^{137} \mathrm{Cs}\right)$ for high-energy gamma rays (density) and americium-241/beryllium $\left({ }^{241} \mathrm{Am} / \mathrm{Be}\right.$ ) for fast neutrons (moisture content). A list of random sampling points for each SSURGO soil unit were generated and sites for sampling were selected from the list on the basis of access availability, both in terms of security related to illegal border activities and to minimize the carrying distance from roads. At each site, 10 sampling points were selected randomly in undisturbed soil. After a standard count to calibrate to the test environment, a stake was driven $50 \mathrm{~mm}$ into the ground to create a measurement hole, the gauge was placed over the hole with as much contact between the base of the gauge and soil surface without moving surficial rock fragments, the probe was inserted, and the radiation returns were counted for 1 minute. The volume of soil sampled was not constant because of variation in density and moisture content, but was about $100 \mathrm{~cm}^{3}$. The gauge calculated wet and dry density as well as moisture content, and only the dry bulk density was used in the analyses. 


\section{Laboratory Measurements}

The 48 bulk density samples were air-dried and an approximately 300 -g subsample was removed using a sample splitter to determine the particle-size distribution. Soil particle-size diameters (D) are measured in millimeters, and D generally is defined as the intermediate, or b-axis, diameter of a particle. Particle-size distributions typically are expressed in phi $(\varphi)$ units, which are defined as:

$$
\mathrm{D}=\varphi^{-2} \text {. }
$$

This subsample was sieved using $1 \varphi$ intervals from $-4 \varphi(16 \mathrm{~mm})$ to $4 \varphi(0.063 \mathrm{~mm})$, with the $4 \varphi$ interval considered to be the break between sand and the silt plus clay fraction. The silt plus clay fraction then was analyzed to separate silt and clay content using the hydrometer technique (Gee and Bauder, 1986).

Many sorting coefficients have been developed, particularly from analyses of hydrodynamic interpretations of sediments and stratigraphy (Bunte and Abt, 2001). Among the many possible sorting coefficients, the Folk sorting coefficient $\sigma_{i}$ (Folk, 1974) was used to measure the degree of sorting for soil particles. The Folk sorting coefficient reflects the slope of the particle-size distribution (Bunte and Abt, 2001), where

$$
\sigma_{\mathrm{i}}=\left(\varphi_{84.1}+\varphi_{50}+\varphi_{15.9}\right) / 3 .
$$

This sorting coefficient uses a scale from about $0.25<\sigma_{\mathrm{i}}<4$, where well-sorted soils have $\sigma_{\mathrm{i}}<0.35$ and poorly sorted soils have $\sigma_{i}>2$. Thus, compaction vulnerability increases with increasing Folk sorting coefficients. The Folk sorting coefficients were scored according to the vulnerability classifications of poorly sorted, $\sigma_{\mathrm{i}}<2.0($ score $=2)$; very poorly sorted, $2 \leq \sigma_{\mathrm{i}} \leq 3($ score $=2.5)$; and extremely poorly sorted, $\sigma_{\mathrm{i}}>3$ (score=3.0).

Proctor compaction analyses were used, combined with particle-size analyses, to develop a quantitative index of compaction vulnerability for soils at ORPI. Proctor compaction tests involve use of a device to apply repeated, standardized pressures to the surface of a disturbed sample to achieve maximum compaction (Bradford and Gupta, 1986). The test consists of compacting soils over a range of moisture contents by applying a standardized normal stress and documents the optimal moisture content for achieving maximum soil compaction (fig. 2). Proctor compaction curves vary with different soil particlesize distributions, but each soil has a lowest maximum density with a corresponding moisture content as well as a high maximum density and moisture content (fig. 3). This allows calculation of several metrics of soil compaction, particularly the differences between these two densities, the water content at maximum and minimum densities, and the difference between maximum compacted and undisturbed densities (fig. 3). 


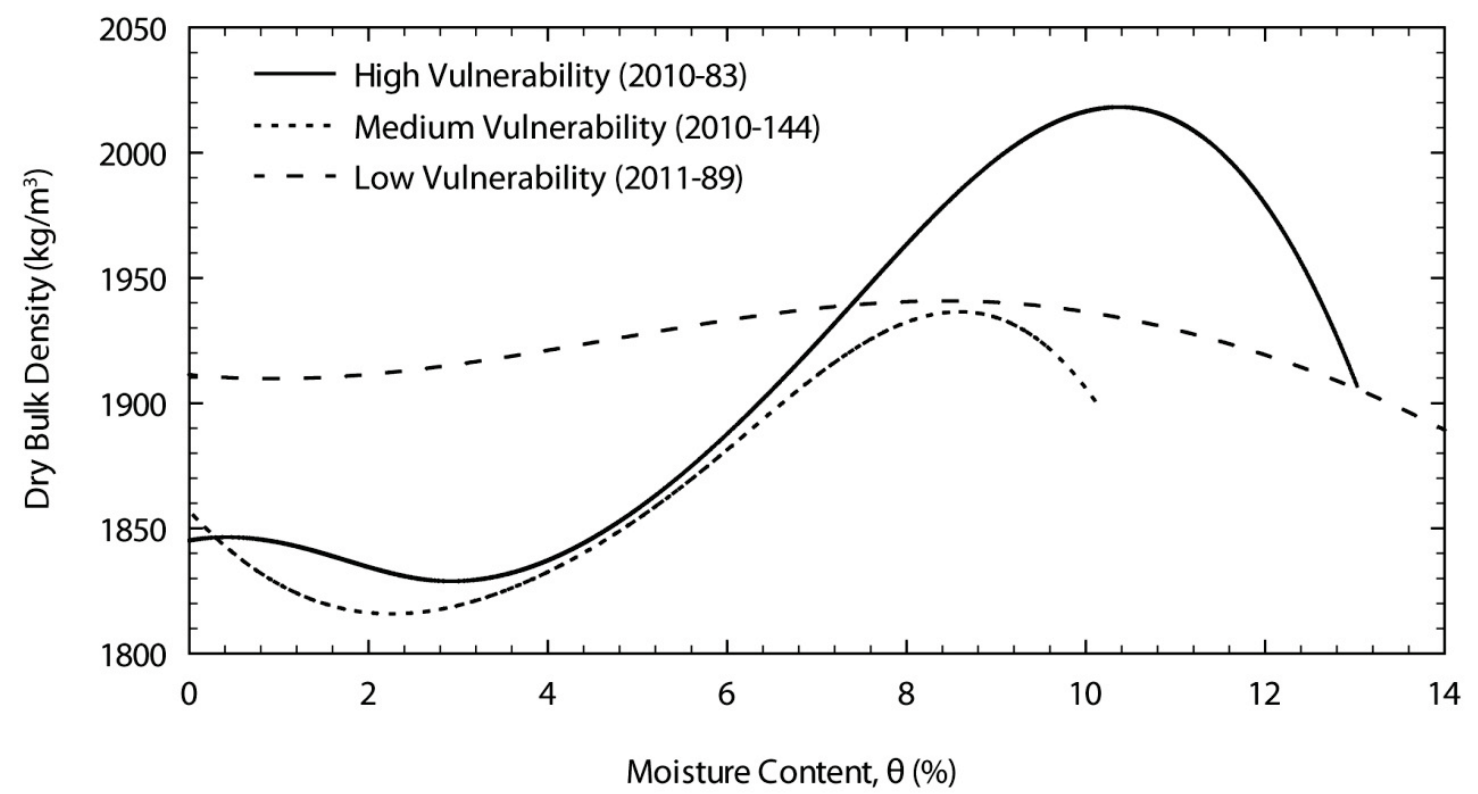

Figure 2. Three examples of Proctor compaction curves illustrating low, medium, and high vulnerability to soil compaction at Organ Pipe Cactus National Monument, southwestern Arizona.

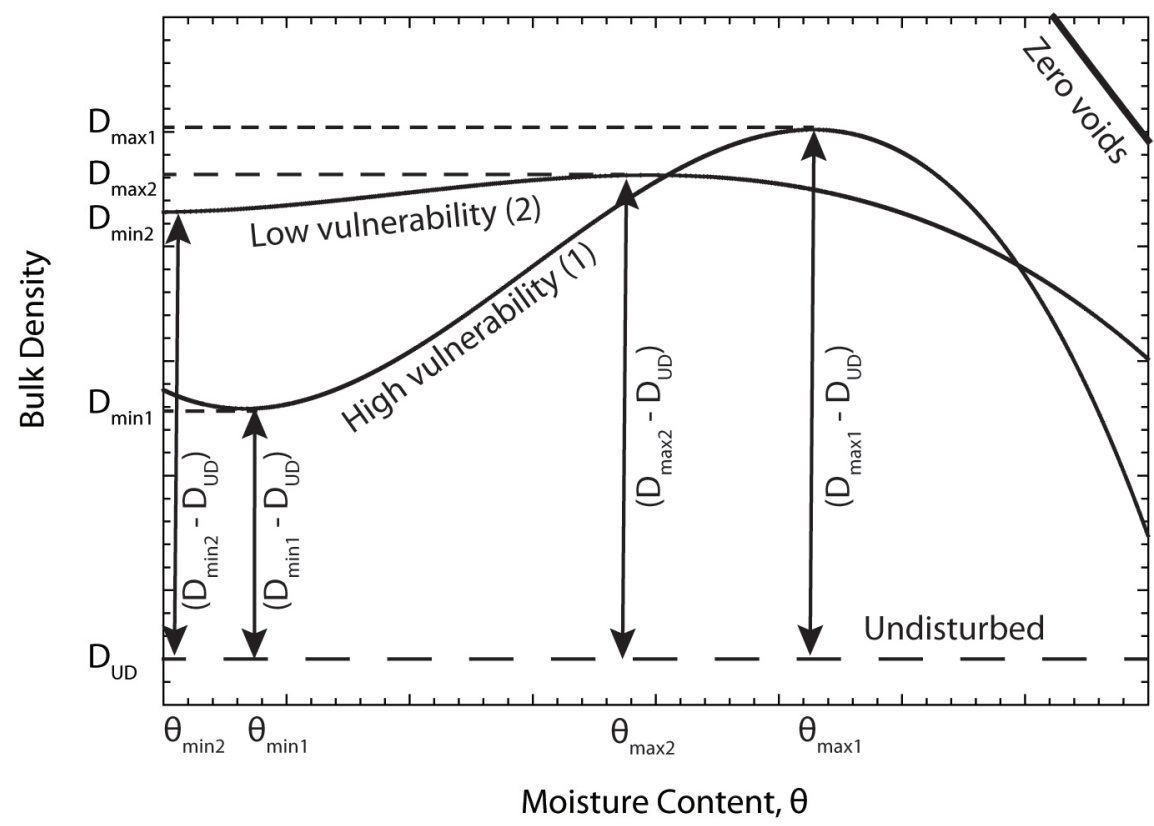

Figure 3. Proctor curves illustrating some of the characteristics used to calculate soil vulnerability to compaction. D, bulk density, and $\theta$, moisture content, at various states as determined using Proctor compaction analyses; $D_{\max }=$

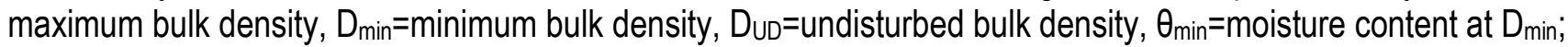
$\theta_{\max }=$ moisture content at $\mathrm{D}_{\max }$. See text and table 3. 
The 48 soil samples from ORPI were compacted to high bulk densities over a range of soil moisture contents using a Ploog Engineering Co., Inc., automatic soil compactor. The standard method outlined in the ASTM standards (ASTMD 698-00a, D2168-02a) was followed. A total of 7 water contents, ranging from 0-16 percent by weight, were measured using a standard mold and 3 lifts with 25 blows per lift. The resulting curve shows minima at a relatively low soil-water content (typically 2-3 percent) and maxima at or near field capacity (8-15 percent). These empirical data typically fit a 3-4 parameter polynomial equation, which typically would allow statistical assessments of compaction vulnerability based on the coefficients. However, the polynomial fit did not adequately represent the Proctor compaction curves, so a cubic-spline curve-fitting routine was used to fit the data and to develop methods for statistically comparing these empirical curves.

The maximum bulk density, especially when compared with the undisturbed bulk density, shows the magnitude of change that occurs with applied surface pressures; the greater the deviation between maximum and undisturbed bulk densities, the more vulnerable the soil to compaction. The differences between the maximum and minimum bulk densities, as well as the moisture contents of these two values, are important measures of compaction vulnerability. This approach was used to develop a scoring system of low, medium, and high vulnerability, as used in the qualitative determinations (table 2).

The difference between maximum and undisturbed densities was scored as:

- 2.0 for $\left(\mathrm{D}_{\max }-\mathrm{D}_{\mathrm{UD}}\right)<250 \mathrm{~kg} / \mathrm{m}^{3}$,

- 2.5 for $250 \leq\left(<\left(D_{\max }-D_{U D}\right) \leq\right)<400 \mathrm{~kg} / \mathrm{m}^{3}$, and

- 3.0 for $\left(\mathrm{D}_{\max }-\mathrm{D}_{\mathrm{UD}}\right)>400 \mathrm{~kg} / \mathrm{m}^{3}$.

None of the soils sampled had low vulnerability characteristics. Similarly, the difference between maximum and minimum bulk densities $\left(\mathrm{D}_{\max }-\mathrm{D}_{\min }\right)$ were scored as:

- for $\left(\mathrm{D}_{\max }-\mathrm{D}_{\min }\right)<18 \mathrm{~kg} / \mathrm{m}^{3}$,

- 1.5 for $18 \leq\left(<\left(D_{\max }-D_{\min }\right) \leq\right)<33 \mathrm{~kg} / \mathrm{m}^{3}$,

- for $33 \leq\left(<\left(D_{\max }-D_{\min }\right) \leq\right)<66 \mathrm{~kg} / \mathrm{m}^{3}$,

- 2.5 for $66 \leq\left(<\left(D_{\max }-D_{\min }\right)<100 \mathrm{~kg} / \mathrm{m}^{3}\right.$, and

- for $\left(D_{\max }-D_{\min }\right)>100 \mathrm{~kg} / \mathrm{m}^{3}$.

Water content at maximum bulk density $\left(\theta_{\max }\right)$ were scored as:

- for $\theta \max <6 \%$ and $\theta_{\max }>16 \%$,

- for $6<\theta_{\max }<8 \%$ and $14<\theta_{\max }<16 \%$, and

- for $8<\theta_{\max }<14 \%$, and $14<\theta_{\max }<16 \%$.

Water content at minimum compaction $\left(\theta_{\min }\right)$ were scored as:

- for $\theta_{\min }<0.5$,

- for $0.5<\theta_{\min }<1$, and

- for $\theta_{\min }>1 \%$.

These five scores then were averaged for each sample to obtain a vulnerability rating for each sample, and each sample was averaged according to soil map unit to obtain a final vulnerability rating.

For each maximally compacted sample still in the Proctor molds, soil penetration resistance was measured using a U.S. Army Corps of Engineers cone penetrometer (Bradford, 1986), model H-4120. This hand-held penetrometer measures the pressure required to push the cone $25.41 \mathrm{~mm}$ into the compacted soil at a constant rate of $3 \mathrm{~cm} / \mathrm{s}$ (Bradford, 1986). A total of 4 measurements were made for each sample at each water content-bulk density pair, and these data were averaged to produce one value of penetration resistance. 
Table 2. Vulnerability scores for selected laboratory measurements of compaction of soils at Organ Pipe Cactus National Monument, southwestern Arizona.

[Abbreviations: $\mathrm{kg} / \mathrm{m}^{3}$, kilogram per cubic meter; =, equals; $<$, less than; >,greater than; \%, percent;,$- \mathrm{D}_{\text {min }}=$ minimum bulk density, $\mathrm{D}_{\mathrm{UD}}=$ undisturbed bulk density, $\theta_{\min }=$ moisture content at $\mathrm{D}_{\min } ; \theta_{\max }=$ moisture content at $\left.\mathrm{D}_{\max }\right]$

\begin{tabular}{|c|c|c|c|c|c|}
\hline $\begin{array}{c}\text { Laboratory } \\
\text { measurement }\end{array}$ & $\begin{array}{c}\text { Low } \\
\text { vulnerability } \\
\text { (score=1) }\end{array}$ & (score $=1.5)$ & $\begin{array}{c}\text { Medium } \\
\text { vulnerability } \\
\text { (score }=2.0)\end{array}$ & (score $=2.5$ ) & $\begin{array}{c}\text { High } \\
\text { vulnerability } \\
\text { (score=3.0) }\end{array}$ \\
\hline $\begin{array}{l}\text { Folk sorting } \\
\text { coefficient, } \sigma_{\mathrm{i}}\end{array}$ & $<2$ & - & $2-3$ & - & $>3$ \\
\hline $\begin{array}{l}\text { Maximum- } \\
\text { undisturbed bulk } \\
\text { density difference } \\
\left(D_{\max }-D_{U D}\right) \\
\mathrm{kg} / \mathrm{m}^{3}\end{array}$ & $<250$ & - & $250-400$ & - & $>400$ \\
\hline $\begin{array}{l}\text { Maximum- } \\
\text { minimum bulk } \\
\text { density difference } \\
\left(D_{\max }-D_{\min }\right) \\
\mathrm{kg} / \mathrm{m}^{3}\end{array}$ & $<18$ & $18-33$ & $33-63$ & $63-100$ & $>100$ \\
\hline $\begin{array}{l}\text { Moisture content at } \\
\text { maximum bulk } \\
\text { density }\left(\theta_{\max }\right), \%\end{array}$ & $<6,>16$ & - & $6-8,14-16$ & - & $8-14$ \\
\hline $\begin{array}{l}\text { Moisture content at } \\
\text { minimum bulk } \\
\text { density }\left(\theta_{\min }\right), \%\end{array}$ & $<0.5$ & - & $0.5-1.0$ & - & $>1.0$ \\
\hline
\end{tabular}

\section{Results}

\section{Qualitative Assessment of Soil Compaction Vulnerability}

The qualitative assessment of soil compaction vulnerability, based on the SSURGO particle-size distributions and the criteria outlined in the section, "Methods," is shown in table 1 and figure 1. A land area of 46,739 ha (35 percent) within ORPI was determined to be highly vulnerable to soil compaction, whereas a land area of 64,654 ha (48 percent) was determined to have medium vulnerability to soil compaction (table 1). 


\section{Particle-Size Distributions and Sorting}

Most soils that were measured at ORPI were poorly sorted, containing a range of particle sizes. The standard soil-texture ternary diagram is inappropriate for these soils because it provides little differentiation given the high sand content and low silt-and-clay content of most soils; instead, a ternary diagram was used, showing gravel, sand, and silt plus clay to display the particle-size distributions (fig. 4). Even with this diagram, most of the ORPI soils plot in the upper part of the diagram, showing more variation in particle-size distribution among the sites. Folk sorting coefficients $\left(\sigma_{\mathrm{i}}\right)$ show that soils sampled at ORPI are very poorly sorted to extremely poorly sorted with only five poorly sorted samples (fig. 5), although more than one-half of the samples were extremely poorly sorted (fig. 5). The particle-size distributions suggest that most soils would have high vulnerability to soil compaction in the absence of large rocks that might absorb surface pressure.

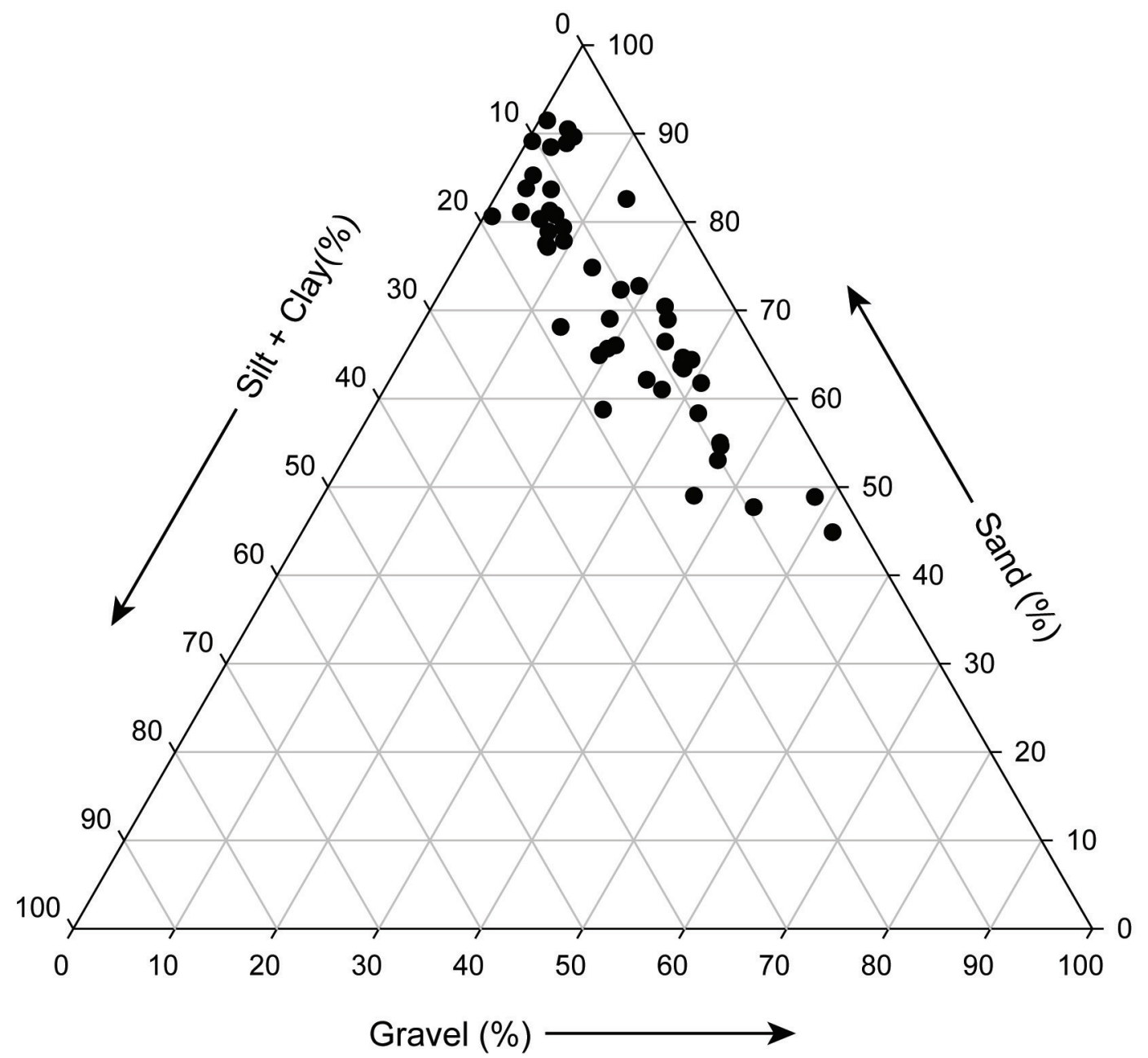

Figure 4. Ternary diagram showing particle-size distributions for 48 soil samples analyzed for compaction vulnerability at Organ Pipe Cactus National Monument, southwestern Arizona. 


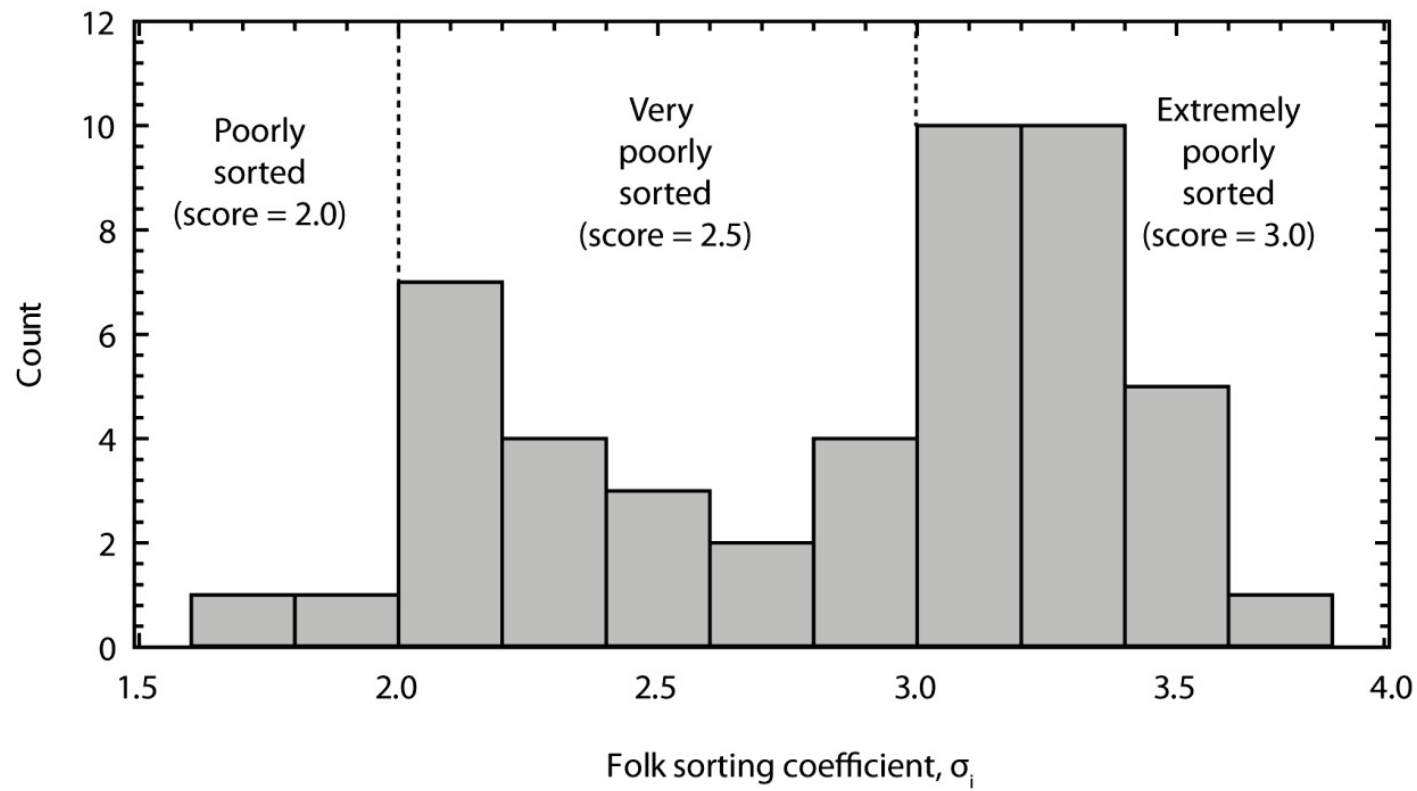

Figure 5. Histogram showing Folk sorting coefficients for soil samples from Organ Pipe Cactus National Monument, southwestern Arizona.

\section{Undisturbed Bulk Density and Laboratory Compaction Measurements}

All SSURGO soil units present at ORPI were sampled for undisturbed bulk density at ORPI (table 3). Bulk densities of undisturbed soils ranged from 1,305 to $1,662 \mathrm{~kg} / \mathrm{m}^{3}$, which is the expected range for these poorly sorted soils with high gravel content. Some of the lowest bulk densities were measured on rocky soils with significant void space at or near the surface because rocks were not cleared from the surface prior to measurements. Most of the soils with low gravel contents had undisturbed bulk densities of near $1,500 \mathrm{~kg} / \mathrm{m}^{3}$, as expected.

The Proctor compaction analyses resulted in maximum densities ranging from 1,657 to 2,039 $\mathrm{kg} / \mathrm{m}^{3}$ (typical density of rock is $2,650 \mathrm{~kg} / \mathrm{m}^{3}$ ), and minimum densities ranging from 1,528 to $1,969 \mathrm{~kg} / \mathrm{m}^{3}$ for 48 soil samples (fig. 6). Moisture contents ranged from 4.3 to 17.3 percent for maximum bulk density, and from 0 to 4.8 percent for minimum bulk density. Histograms were created of the differences between maximum and undisturbed ( $\left.D_{\max }-D_{\text {UD }}\right)$ and maximum and minimum bulk densities $\left(D_{\max }-D_{\min }\right)$ (figs. $6 \mathrm{~A}$, B), as well as histograms of maximum and minimum moisture contents (figs. 6C, D). The scoring criteria then was applied to rate each soil. Four soils-Antho soils (very gravelly variant), Gachado very cobbly loam, Gilman very fine sandy loam (saline), and Torrifluvents — rated a consistent high vulnerability; all other soils had various scores ranging from medium to high, but the average score for all high vulnerability soils was greater than 2.5 . 
Table 3. Undisturbed dry bulk densities for soils at Organ Pipe Cactus National Monument, southwestern Arizona. $\left[\mathrm{kg} / \mathrm{m}^{3}\right.$, kilograms per cubic meter, $\mathrm{n}=10$ measurements $]$

\begin{tabular}{lcc}
\hline \multicolumn{1}{c}{ Soil map unit } & $\begin{array}{c}\text { Mean dry bulk } \\
\text { density } \\
\left(\mathbf{k g} / \mathbf{m}^{3}\right)\end{array}$ & $\begin{array}{c}\text { Standard } \\
\text { deviation }\end{array}$ \\
\hline Ajo very cobbly sandy loam & 1,352 & 71 \\
Ajo very gravelly loam & 1,305 & 68 \\
Antho fine sandy loam & 1,595 & 53 \\
Antho soils, very gravelly variant & 1,556 & 31 \\
Cherioni gravelly very fine sandy loam & 1,548 & 108 \\
Cipriano gravelly loam & 1,362 & 31 \\
Gachado very cobbly loam & 1,486 & 90 \\
Gilman very fine sandy loam & 1,403 & 66 \\
Gilman very fine sandy loam, saline & 1,408 & 73 \\
Growler-Antho Complex & 1,476 & 49 \\
Gunsight very gravelly loam & 1,622 & 24 \\
Gunsight very gravelly loam & 1,388 & 51 \\
Harqua very gravelly loam & 1,662 & 55 \\
Harqua very cobbly loam & 1,491 & 116 \\
Harqua-Gunsight Complex & 1,452 & 96 \\
Laveen loam & 1,507 & 44 \\
Lomitas very stony loam & 1,524 & 115 \\
Perryville very cobbly fine sandy loam & 1,429 & 83 \\
Perryville very cobbly fine sandy loam & 1,407 & 50 \\
Rillito gravelly sandy loam & 1,579 & 76 \\
Rock land & 1,523 & 73 \\
Rock outcrop & 1,406 & 69 \\
Stony land- Rock outcrop association & 1,597 & 39 \\
Torrifluvents & 1,435 & 160 \\
\hline & & \\
\hline
\end{tabular}



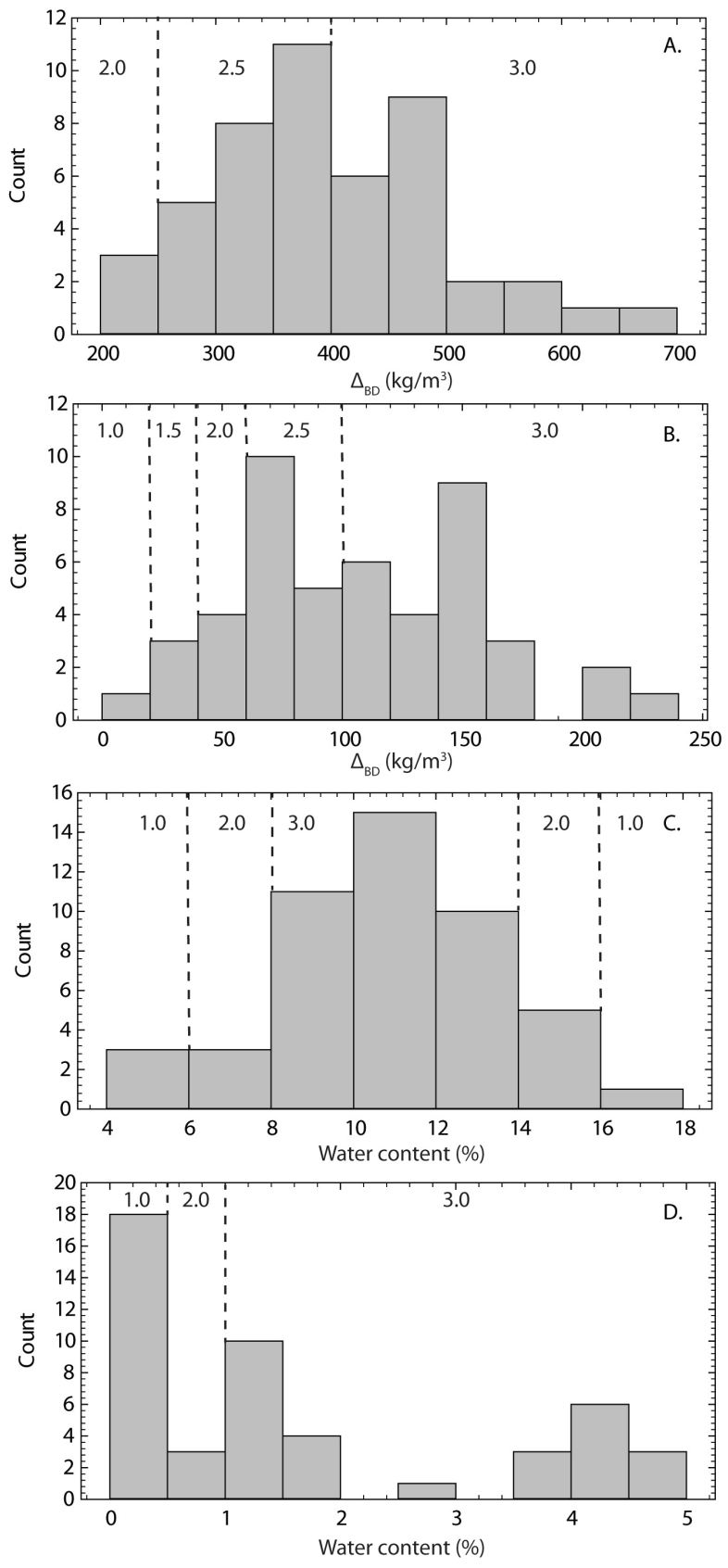

Figure 6. Histograms showing Proctor compaction curves (see fig. 3) for (A) maximum bulk density minus undisturbed bulk density ( $\left(D_{\max }-D_{u d}\right)$, (B) maximum minus minimum bulk density $\left(D_{\max }-D_{\min }\right),(C)$ water content at maximum density, and $(D)$ water content at minimum density, with the scoring system for compaction vulnerability shown in groups delineated with dashed lines. 
Penetration-resistance tests show some problems with using penetrometers to assess soil compaction (fig. 7). The maximum penetration resistance typically occurred at low water contents and bulk densities than the maximum compaction, indicating interactions among penetration resistance, bulk density, and moisture content for each soil particle-size distribution. The average water content for maximum penetration resistance was $10.7 \pm 2.4$ percent (mean \pm 1 standard deviation), and the moisture content for maximum bulk density averaged $11.0 \pm 2.0$ percent; the paired-sample t-test shows these values are not significantly different $(\mathrm{df}=47, \mathrm{t}=1.516, \mathrm{p}=0.136)$. Because penetration resistance is a function of particle-size distribution, moisture content, and bulk density, it introduced greater variability when compared to bulk density alone.

A multiple linear regression was done using maximum penetration resistance as the dependent variable and Folk sorting coefficient, and bulk density at the maximum resistance and moisture content at the maximum resistance as the independent variables. This analysis resulted in the equation:

$$
\mathrm{P}=-3.742-2.191 \cdot \theta_{\min }-0.186 \cdot \theta_{\max }-0.002 \cdot\left(\mathrm{D}_{\max }-\mathrm{D}_{\mathrm{UD}}\right)+0.082 \cdot\left(\mathrm{D}_{\max }-\mathrm{D}_{\min }\right)+9.689 \cdot \sigma_{\mathrm{i}}(3)
$$

with a multiple $\mathrm{R}^{2}=0.244(\mathrm{df}=44, \mathrm{t}=-0.233, \mathrm{p}=0.817)$. Although this linear regression is not significant, it suggests that sorting, as reflected by the Folk $\sigma_{i}$, has the largest effect on penetration resistance.

\section{Quantitative Assessment of Soil Compaction Vulnerability}

We averaged the scores by soil for each of the five laboratory results used to reflect compaction vulnerability (table 1; figs. 5, 6), resulting in a vulnerability score for each of the 48 soil samples. The resulting map (fig. 8) differs significantly from the qualitative assessment of vulnerability (fig. 1) in several ways (fig. 9). First, most of the bedrock surfaces, qualitatively rated as low vulnerability, were not sampled and could not be scored based on laboratory tests. Second, the vulnerability classifications of several soil units shifted as a result of the laboratory analyses; four soils changed from medium to high vulnerability, five soils changed from high to medium vulnerability, and one soil changed from low to high vulnerability (table 1).

On the basis of these analyses (fig. 8), 80,870 ha (60 percent) of the 133,800 ha at ORPI has a high vulnerability to compaction compared with the 24,655 ha (18.4 percent) determined from qualitative assessment (laboratory analyses were not performed on the remaining 21 percent of area with soils). The area of high vulnerability soils increased 73 percent from the 46,740 ha assessed qualitatively (table 1). The analyses determined that the area of medium vulnerability was 24,655 ha, a decrease from 64,654 ha determined qualitatively. Only one low vulnerability soil was sampled, thus precluding statistical analysis. Soils over an area of 28,297 ha were not sampled, and two soils qualitatively rated as low vulnerability soils were present in this area. 

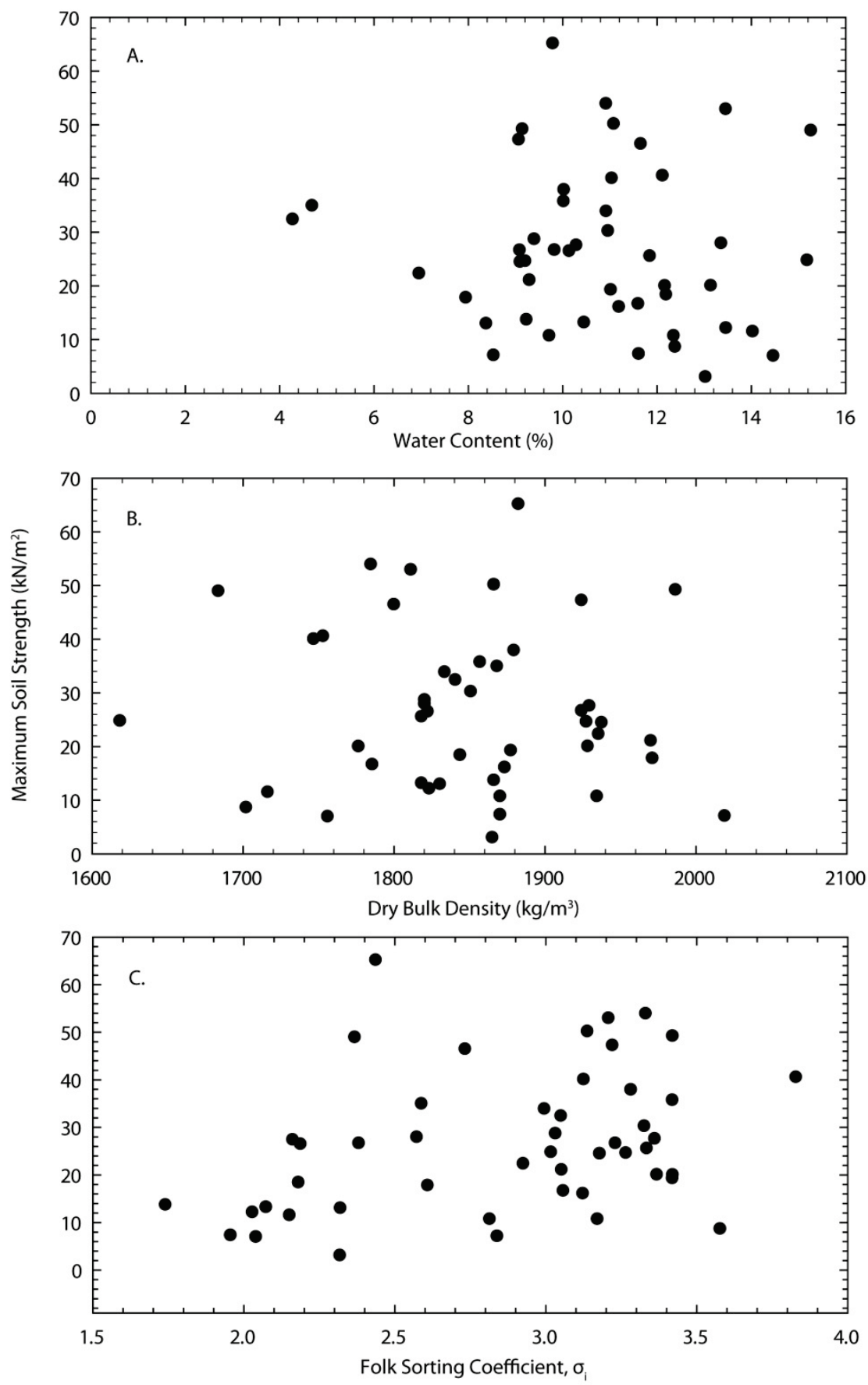

Figure 7. Graphs showing maximum soil strength compared to (A) moisture content, (B) bulk density, and (C) Folk sorting coefficient, $\sigma_{i}$. 


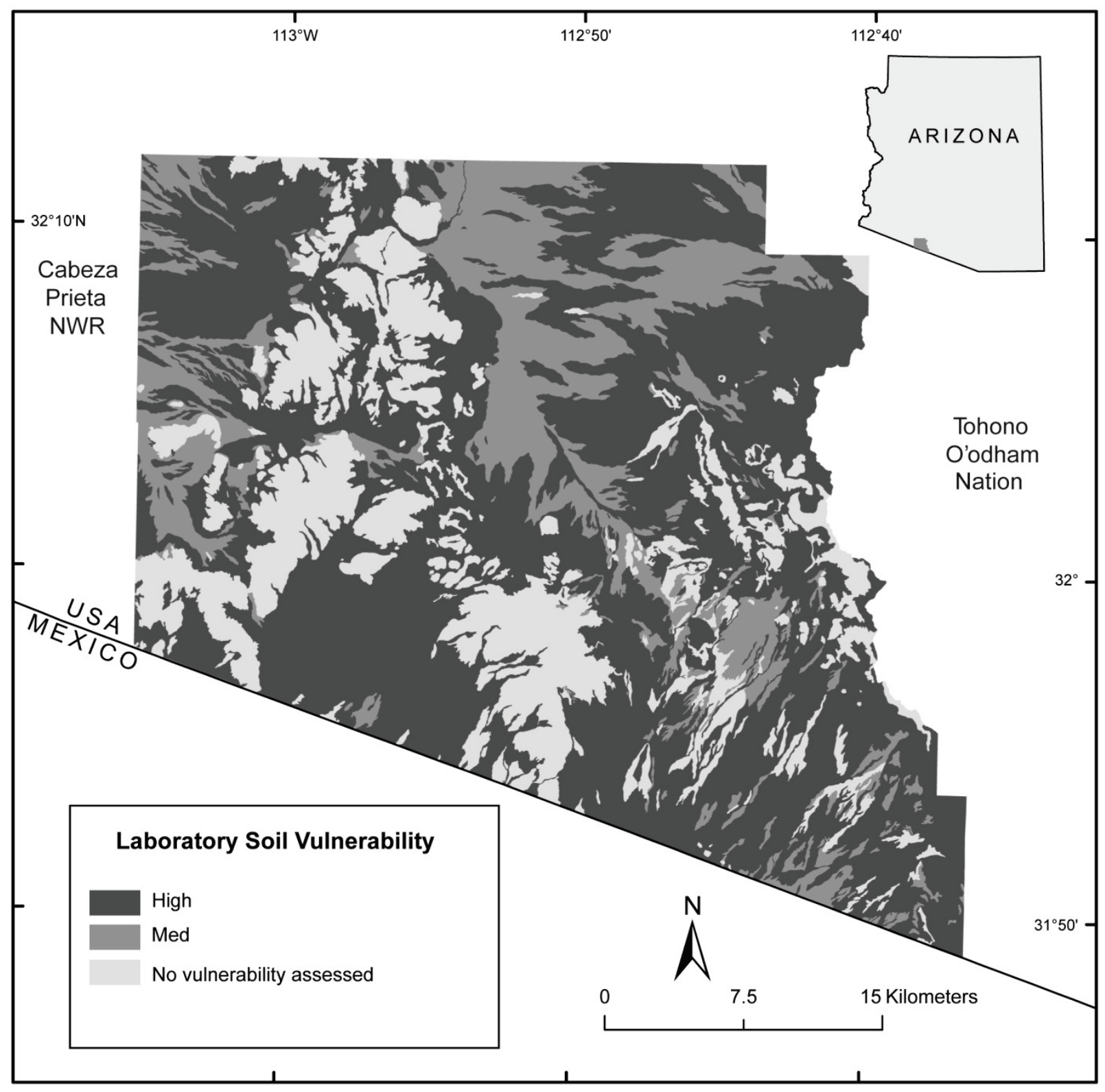

Figure 8. Map showing soil vulnerability to soil compaction based on laboratory measurements, Organ Pipe Cactus National Monument, southwestern Arizona. 


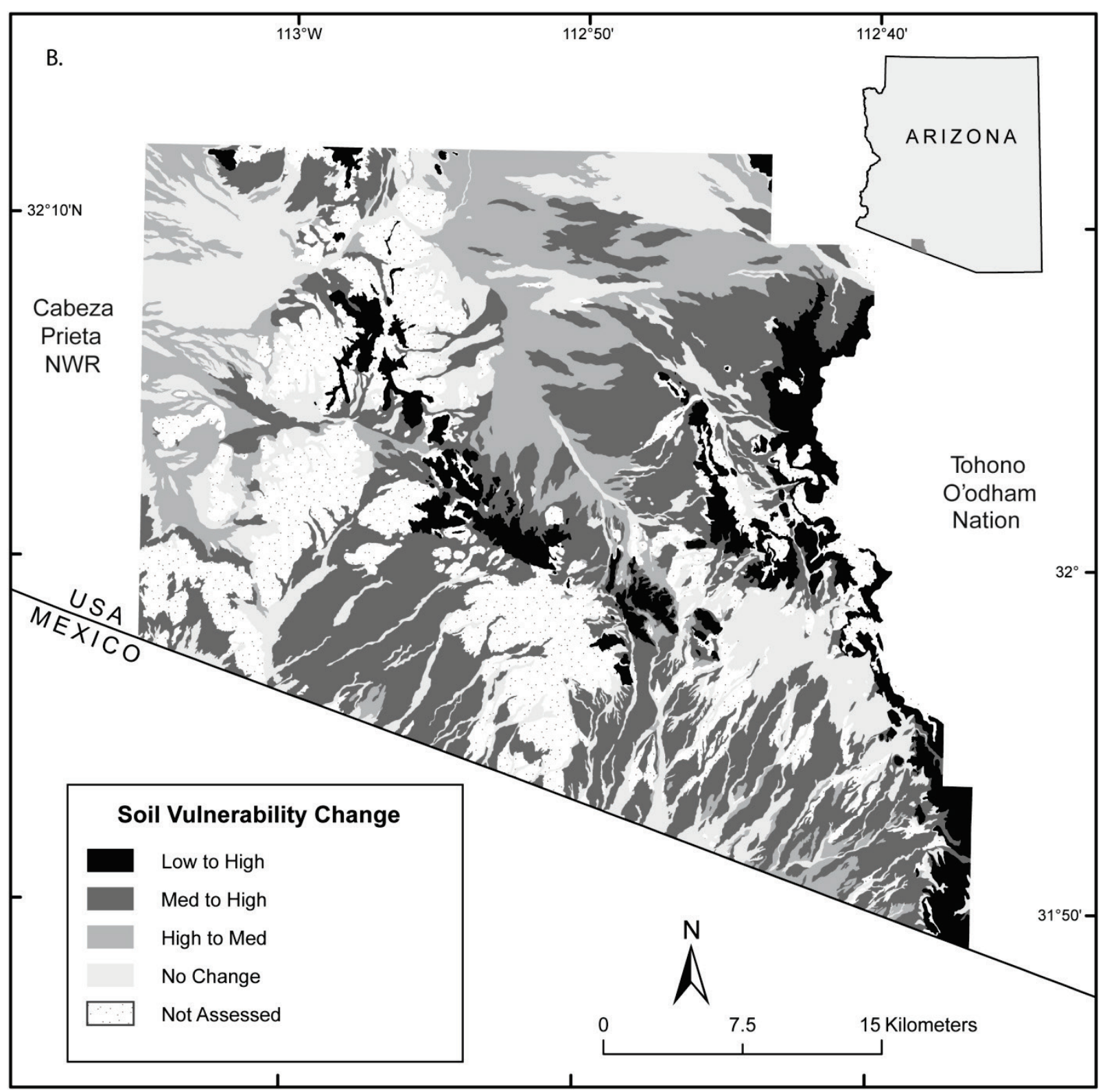

Figure 9. Map showing changes in classifications of soil compaction vulnerability from qualitative (fig. 1) to quantitative (fig. 8) assessments, Organ Pipe Cactus National Monument, southwestern Arizona. 


\section{Discussion and Conclusions}

Field and laboratory measurements were used to assess soil vulnerability to compaction from applied surface pressure for soils at Organ Pipe Cactus National Monument (ORPI) in southwestern Arizona. Our analyses determined that 60 percent of ORPI had soils highly vulnerable to compaction, 18 percent had soils of medium vulnerability, and no areas had low vulnerability, although soils covering 21 percent of the national park unit were not sampled owing to access restrictions or difficult terrain. Results from the field and laboratory measurements differed significantly from qualitative assessments of vulnerability based on widely available digital soils data (Soil Survey Geographic, or SSURGO), which suggests that the easily performed qualitative assessments, although potentially useful as guides for land managers, should be tested with quantitative measures. For ORPI, this is underscored by comparing the qualitative assessment with the quantitative analysis for Gunsight very gravelly loam, which covers 24,824 ha (18.6 percent) and changed from a qualitative rating of medium vulnerability to a rating of high vulnerability on the basis of laboratory analyses (table 1).

Four soils consistently scored as highly vulnerable to compaction in the analyses. Antho soils (very gravelly variant), Gilman very fine sandy loam (saline), and Torrifluvents were rated as highly vulnerable, both on the qualitative and quantitative assessments. These soils occupy an area of 7,040 ha at ORPI. However, the Gachado very cobbly loam, which qualitatively was rated with medium vulnerability, became highly vulnerable, but this soil only occupies 621 ha at ORPI. Only one soil — Cipriano gravelly loam - was qualitatively and quantitatively rated with medium vulnerability, which shows that field variability in compaction characteristics is too high to be assessed with SSURGO data alone.

The SSURGO database - which contains generalized particle-size data in a geospatial framework and is available for most of Arizona and much of the continental United States - is both useful and problematic in assessing compaction vulnerability. SSURGO provides data averaged over map areas (polygons), some of which are very large, and, as a result, these data cannot account for continuous spatial variability in surficial soil properties, which can be extreme in desert landscapes. Although as many as four samples were obtained from a soil at ORPI (table 1), laboratory tests from only one sample typically were used to characterize the compaction vulnerability of a soil. The analyses indicate that SSURGO data alone are of insufficient resolution to differentiate medium levels from high levels of compaction vulnerability. Because of the soils present at ORPI, as well as our ability to sample, we could not reliably determine if the soils mapped as either well sorted or very rocky within the SSURGO database would rate as low vulnerability from field and laboratory data.

The high content of particles greater than $16 \mathrm{~mm}$, (otherwise referred to here as coarse gravel) is another problem with laboratory assessment of soil vulnerability for coarse desert soils. ASTM testing standards require that particles greater than $16 \mathrm{~mm}$ b-axis diameter be removed from samples prior to Proctor analyses because they have problematic interactions with the compacting hammer in the Proctor molds. High concentrations of these particles, however, are expected to reduce compaction vulnerability by absorbing applied stress in particle-to-particle contacts instead of pore-space reductions. The change in the Gachado very cobbly loam from medium to high vulnerability may be an example of the problems experienced with removal of large particles prior to Proctor analyses. Experimental work with soils in the field (Webb and others, 2013) may be the solution to this problem, but this type of work is more expensive and time consuming than the laboratory analyses described in this paper. 
Our map showing soil vulnerability to compaction does not consider other adverse effects of applied surface pressures. It is unclear whether soils that are highly vulnerable to soil compaction also are highly vulnerable to other environmental problems as well, particularly soil-erosion potential. Gilman very fine sandy loam, which occurs in northern ORPI, provides a good example. Although laboratory analyses indicated it has medium vulnerability to soil compaction, it is the most wind- and water-eroded soil at ORPI as a result of long-term grazing, human trampling, and vehicle disturbance (P. Holm, National Park Service, written commun., 2012). On the western boundary of ORPI, experimental work conducted in 2010 found extensive rutting and disruption in this soil while dry (Webb and others, 2013). Rutman (1996) found that severe erosion problems occurred in Gilman very fine sandy loam (saline) at several sites in the northern part of ORPI, and this saline variant is highly vulnerable to compaction. Further work is required to establish if any quantitative connection exists between compaction and erosion vulnerability.

Desert soils have important subsurface properties that must be considered when assessing compaction vulnerabilities using laboratory analyses of non-intact soil samples. In the upper 10 centimeters of their profiles, most intact (uneroded) desert soils have Av (vesicular A) horizons (either underlying desert pavement or at the surface) that vary in texture from sandy to silty loams. The vesicles in this horizon are macropores that applied surface pressure can easily collapse, particularly when wet, creating a dense platy horizon with low infiltration capacity. Mixed with gravel or sand, this zone can be highly vulnerable to compaction and differs from soils of more mesic regions. This fine structure cannot be preserved for laboratory analyses, and vulnerability to soil compaction must be assessed using field experiments.

Management practices designed to minimize adverse environmental effects of surface disturbances should consider soil compaction vulnerability analyses as one part of an overall strategy to protect natural resources, to plan for their use, and to monitor for potential adverse responses. The biggest problem with the approach of this study was the low resolution of geospatial data on soil physical properties as illustrated with our experience with SSURGO data at ORPI. High-resolution data on surficial particle-size distributions would help to improve geospatial analyses of soil vulnerability to disturbances.

\section{Acknowledgments}

The National Park Service and the U.S. Geological Survey provided funding for this research. We thank Sarah M.S. Howard, Ed M. Kuklinski, and Justine L. McCune for their collection of samples at ORPI. Helen Raichle helped with field work and provided the geographic information system analyses, and Trevor Birt and Margaret Snyder helped with laboratory analyses. Peter Holm provided climate data and other background material on Organ Pipe Cactus National Monument. This manuscript was critically reviewed by Peter Holm, Jayne Belnap, and three anonymous reviewers. 


\section{References Cited}

Adams, J.A., Stolzy, L.H., Endo, A.S., Rowlands, P.G., and Johnson, H.B. 1982, Desert soil compaction reduces annual plant cover: California Agriculture, v. 36, p. 6-7.

American Society for Testing and Materials International, 2007, ASTM Standard D698-07-Standard test methods for laboratory compaction characteristics of soil using standard effort: West Conshohocken, Pennsylvania, ASTM International,, doi:10.1520/D0698-07E01.

Bodman, G.B., and Constantin, G.K., 1965, Influence of particle-size distribution in soil compaction: Hilgardia, v. 36 , no. 15 , p. 567-591.

Bradford, J.M., 1986, Penetrability, in Klute, A., ed., Methods of soil analysis, Part 1-Physical and mineralogical methods: Madison, Wisconsin, American Society of Agronomy, p. 463-478.

Bradford, J.M., and Gupta, S.C., 1986, Compressibility, in Klute, A., ed., Methods of soil analysis, Part 1-Physical and mineralogical methods: Madison, Wisconsin, American Society of Agronomy. p. 479-492.

Brooks, M.L., Matchett, J.R., and Berry, K.H., 2006, Effects of livestock watering sites on alien and native plants in the Mojave Desert, USA: Journal of Arid Environments, v. 67, p. 125-147.

Bunte, K., and Abt, S.R., 2001, Sampling surface and subsurface particle-size distributions in wadable gravel- and cobble-bed streams for analyses in sediment transport, hydraulics, and streambed monitoring: Rocky Mountain Research Station General Technical Report RMRS-GTR-74, U.S. Department of Agriculture, Forest Service, Fort Collins, Colorado.

Campbell, C.E., 1972, Some environmental effects of rural subdividing in an arid area-A case study in Arizona: Journal of Geography, v. 71, p. 147-154.

Chamberlain, E., 1972, Soil survey_Organ Pipe Cactus National Monument, Pima County, Arizona-A special report: Soil Conservation Service, National Park Service, and Arizona Agricultural Experiment Station, M7-L-22776.

Chen, Y., Li, Y., Zhao, X., Awada, T., Shang, W., and Han, J., 2012, Effects of grazing exclusion on soil properties and on ecosystem carbon and nitrogen storage in a sandy rangeland of Inner Mongolia, Northern China: Environmental Management, doi:10.1007/s00267-012-9919-1.

Folk, .RL., 1974, Petrology of sedimentary rocks: Austin, Texas, Hemphill Publishing Company. Fredlund, D.G., and Rahardjo, H., 1993,. Soil mechanics for unsaturated soils: New York, Wiley. Gee, G.W., and Bauder, J.W., 1986, Particle-size analysis, in Klute, A., ed., Methods of soil analysis, Part 1-Physical and mineralogical methods: Madison, Wisconsin, American Society of Agronomy, p. 383-411.

Goossens, D., and Buck, B., 2009, Dust dynamics in off-road vehicle trails-Measurements on 16 arid soil types, Nevada, USA: Journal of Environmental Management, v. 90, p. 3458-3469.

Goossens, D., and Buck, B., 2011, Effects of wind erosion, off-road vehicular activity, atmospheric conditions and the proximity of a metropolitan area on PM10 characteristics in a recreational site: Atmospheric Environment, v. 45, p. 94-107.

Greacen, E.L., 1960, Water content and soil strength: Journal of Soil Science, v. 11, no. 2, p. 313-333.

Iverson, R.M., 1980, Processes of accelerated pluvial erosion on desert hill slopes modified by vehicular traffic: Earth Surface Processes, v. 5, p. 369-388.

Iverson, R.M., Hinckley, B.S., Webb, R.H., and Hallet, B. 1981, Physical effects of vehicular disturbances on arid landscapes: Science, v. 212, p. 915-917.

Jones, R.J.A., Spoor, G., and Thomasson, A.J., 2003, Vulnerability of subsoils in Europe to compactionA preliminary analysis: Soil and Tillage Research, v. 73, p. 131-143.

Krzysik, A.J., 1985, Ecological assessment of the effects of army training activities on a desert ecosystem - National Training Center, Fort Irwin, California: Champaign, Illinois, U.S. Army Corps of Engineers, Construction Engineering Research Laboratory, Technical Report N-85/13. 
Leu, M., Hanser, S.E., and Knick, S.T., 2008, The human footprint in the West-A large-scale analysis of anthropogenic impacts: Ecological Applications, v. 18, p. 1119-1139.

Liddle, M.J., 1975, A selective review of the ecological effects of human trampling on natural ecosystems: Biological Conservation, v. 7, p. 17-36.

Liddle, M.J., and Grieg-Smith P., 1975, A survey of tracks and paths in a sand-dune ecosystem, 1-Soils: Journal of Applied Ecology, v. 12, no. 3, p. 893-908.

Lovich, J.E., and Bainbridge, D., 1999, Anthropogenic degradation of the southern California desert ecosystem and prospects for natural recovery and restoration: Environmental Management, v. 24, no. 3, p. 309-326.

McCarthy, L.E., 1996, Impact of military maneuvers on Mojave Desert surfaces-A multiscale analysis: Tucson, University of Arizona, Ph.D. dissertation.

Muro, T., and O'Brien, J. 2004,. Terramechanics_Land Locomotion Mechanics: Tokyo, AA Balkema, $322 \mathrm{p}$.

Nauman, T., 2009, Digital soil-landscape classification for soil survey using Aster satellite and digital elevation data in Organ Pipe Cactus National Monument, Arizona: Tucson, University of Arizona, M.S. thesis.

National Park Service, 2006, Management policies 2006: Washington, D.C., Government Printing Office, National Park Service, 176 p.

National Park Service, 2008, Annual climate summary for 2007: National Park Service, Organ Pipe Cactus National Monument, Arizona.

National Park Service, 2010, Digital geologic map of Organ Pipe Cactus National Monument and Vicinity, Arizona (NPS, GRD, GRI, ORPI, ORPI digital map): Lakewood, Colorado, National Park Service, Geologic Resources Inventory Program, Geospatial Dataset-1049253.

Natural Resources Conservation Service [n.d.], Soil Survey Geographic (SSURGO) database for Organ Pipe Cactus National Monument, Arizona: U.S. Department of Agriculture. Natural Resources Conservation Service, Soil Survey Staff, accessed March 3, 2010, at http://soildatamart.nrcs.usda.gov.

Pearthree, P.A., Youberg, A., and Young, J.J., 2011, Geologic map of the Tillotson Peak 7 1/2' Quadrangle and part of the Mount Ajo 7 1/2' Quadrangle, Organ Pipe Cactus National Monument, Pima County, Arizona: Tucson, Arizona Geological Survey Digital Geologic Map DGM-73.

Prose, D.V., and Wilshire H.G., 2000, The lasting effects of tank maneuvers on desert soils and intershrub flora: U.S. Geological Survey Open-File Report 2000-512, http://geopubs.wr.usgs.gov/open-file/of00512/, $22 \mathrm{p}$.

Prose, D.V., Metzger S.K., and Wilshire H.G., 1987, Effects of substrate disturbance on secondary plant succession-Mojave Desert, California: Journal of Applied Ecology, v. 24, p. 305-313.

Rutman, S., 1996, An assessment of accelerated erosion and its management at Organ Pipe Cactus National Monument: NPS Report.

Snyder, C.T., Frickel, D.G., Hadley, R.F., and Miller, R.F., 1976, Effects of off-road vehicle use on the hydrology and landscape of arid environments in central and southern California: U.S. Geological Survey Water-Resources Investigations Report 76-99, 45 p., http://pubs.er.usgs.gov/publication/wri7699.

U.S. Fish and Wildlife Service, 2011, Vehicle trails associated with illegal border activities on Cabeza Prieta National Wildlife Refuge-July 2011: U.S. Fish and Wildlife Service, Cabeza Prieta National Wildlife Refuge, Ajo, Arizona.

Vasek, F.C., Johnson, H.B., and Eslinger, D.H., 1975, Effects of pipeline construction on creosote bush scrub vegetation on the Mojave Desert: Madrono, v. 23, p. 1-13. 
Vogel, J., and Hughson, D.L., 2009, Historical patterns of road networks in Mojave National Preserve, in Webb, R.H., Fenstermaker, L.F., Heaton, J.S., Hughson, D.L., McDonald, E.V., and Miller, D.M., eds., The Mojave Desert—Ecosystem processes and sustainability: Reno, University of Nevada Press, p. $196-210$.

Vorhees, W.B., Senst, C.G., and Nelson, W.W., 1978, Compaction and soil structure modification by wheel traffic in the northern corn belt: Soil Science Society of America Journal, v. 42:, p. 44-349.

Weaver, T., and Dale, D., 1978, Trampling effects of hikers, motorcycles, and horses in meadows and forests: Journal of Applied Ecology, v. 15, p. 451-457.

Webb, R.H., 1983, Compaction of desert soils by off-road vehicles, in Webb, R.H., and Wilshire, H.G., eds., Environmental effects of off-road vehicles: New York, Springer-Verlag, p 51-79.

Webb, R.H., 2002, Recovery of severely compacted soils in the Mojave Desert, California, USA: Arid Lands Research and Management, v. 16, p. 291-305.

Webb, R.H., Esque, T.C., Nussear, K.E., and Sturm, M., 2013, Disruption rates for one vulnerable soil in Organ Pipe Cactus National Monument, Arizona, USA: Journal of Arid Environments, v. 95, p. 75-83, http://dx.doi.org/10.1016/j.jaridenv.2013.03.016.

Williams, F.H.P., and MacLean, D.J., 1950, The compaction of soil-A study of the performance of plant: London, Department of Scientific and Industrial Research, Road Research Laboratory, Technical Paper No. 17.

Youberg, A., and Pearthree, P.A., 2011, Geologic map of parts of the Lukeville, Diaz Peak, south of Lukeville and Blankenship Wells 7 1/2" Quadrangles, Organ Pipe Cactus National Monument, Pima County, Arizona: Arizona Geological Survey Digital Geologic Map DGM-74, Tucson, Arizona.

Young, J.J., and Pearthree, P.A., 2011, Geologic map of the Armenta Well $7 \frac{1}{1} 2^{\prime}$ Quadrangle and part of the Gunsight $71 \frac{1}{2}$ " Quadrangle, Organ Pipe Cactus National Monument, Pima County, Arizona: Arizona Geological Survey Digital Geologic Map (DGM-72), Tucson, Arizona. 
This page left intentionally blank 
Publishing support provided by the U.S. Geological Survey Publishing Network, Tacoma Publishing Service Center

For additional information contact:

Director, Western Ecological Research Center

U.S. Geological Survey

3020 State University Drive East

Sacramento, California 95819

http://werc.usgs.gov/ 


\section{हू}

$\sum_{0}^{0}$

ฏ

울

家

\&

을

ํㅗㄹ.

흠.

高

흠.

$\stackrel{0}{\circ}$

옹

뭄

8

ต

골.

흠

3

홀

is

产

$\stackrel{\$}{\stackrel{9}{\Phi}}$

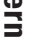

곡.

을

!

要

亭

ग्ञ

음

ก

辛 